\title{
To assess the fresh water algal diversity in relation to water quality from river Panjkora, district Dir lower, Pakistan
}

Muhammad Shuaib ${ }^{1 *}$, Kashif Ali², Umar Zeb ${ }^{3}$, Sajjad Ahmed ${ }^{4}$, Sajjad Ali $^{5}$, Ikramullah Khan ${ }^{6}$ and Fida Hussain ${ }^{7}$

1. School of Ecology and Environmental Science, Yunnan University, No.2 North Cuihu Road, Kunming, Yunnan, 650091, P.R-China

2. Department of Botany, Islamia College University Peshawar-Pakistan

3. Key Laboratory of Resources Biology and Biotechnology in Western China, Ministry of Education, College of Life Science, Northwest University, Xian 710069-China

4. Key Laboratory of Molecular Epigenetics of Ministry of Education, School of Life Science, Northeast Normal University, Jilin-China

5. Department of Botany, Bacha Khan University Charsadda-Pakistan

6. Department of Botany, Abdul Wali Khan University Mardan-Pakistan

7. School of Resources, Environmental and Chemical Engineering Nanchang University, Nanchang Jiangxi-China

*Corresponding author's email: zeyadz44@yahoo.com

Citation

Muhammad Shuaib, Kashif Ali, Umar Zeb, Sajjad Ahmed, Sajjad Ali, Ikramullah Khan and Fida Hussain. To assess the fresh water algal diversity in relation to water from river Panjkora, district Dir lower, Pakistan. Pure and Applied Biology. Vol. 6, Issue 2, pp645-656. http://dx.doi.org/10.19045/bspab.2017.60067

\begin{tabular}{llll}
\hline \hline Received: 07/03/2017 & Revised: 29/04/2017 & Accepted: 04/05/2017 & Online First: 08/05/2017 \\
\hline \hline
\end{tabular}

\section{Abstract}

Thirty-five species belong to fresh water are taxonomically identified with the quality of water bodies from the remote areas. The samples are collected from the river Panjkora different sites during February 2015 to August 2016. Algae are collected, identified and describe in the area for the first time and exploration of the local species are presented in this article. The total 35 species belongs to 16 Genera, 15 Families, 12 Orders, 9 classes and 5 Phylum's having phylum Chlorophyta includes $22(63 \%)$ species, Charophyta 6(17\%) species, Euglenophyta 4 (11\%) Species, Ochrophyta $2(6 \%)$ species and Rhodophyta $1(3 \%)$ species. The most dominant are Genus Euglena 4 species (24\%), Genera Ankistrodesmus, Microspora, Spirogyra and Ulothrix has 3 Species (17\%), Genera Chaetophora, Chlamydomonas, Cladophora, Nitella, Oocystis, Stigeoclonium and Volvox has 2 species (12\%), Asterococcus, Batrachospermum, Chlorochromonas, Synura, Zygogonium each has 1 species (6\%).It is the first inclusive taxonomical study in river Panjokora and its surrounding area, the river Panjkora is rich of algal species further investigations were needed.

Keywords: Physico-chemical characteristics; Algal diversity; Freshwater; River Panjkora; Dir lower; Pakistan

\section{Introduction}

Algae are widespread in their existence found in every moist place including moist soil throughout the year. In the world lot of taxonomic work is done to classify the algal species but the most promising work is done on freshwater algal species. Algae are the important group of the organism and affect 
human life both positively and negatively and it is a source of food [1]. Algae are the unicellular or multicellular most important photosynthetic life on earth having no true roots, stems and leaves, mostly found in the fresh water and moist places [2]. Algae contribute oxygen to the environment [3]. It is the primary producers and found in all ecosystems help in the different food chains. It is a direct and indirect source of food for fish, aquatic animals, and men also. Many algae were identified from the freshwater habitats by Hussain et al. [4], Hussain et al. [5] and Leghari et al. [6]. From Karachi fresh water algae revealed by Aliya et al. [7], Leghari, [8], the taxonomic survey of freshwater algae from Multan by Ghazala et al. [9]. A checklist of freshwater algae from Baluchistan by Hussain et al. [4]. From Azad Kashmir and Panjab Taxonomic studies were done [10]. Algae are different form and shapes, some are one cell and some are combining together and live in the form of colony and these worked independently. Dir lower is rich of plant diversity [11]. The current literature revels that there is no study done before on fresh water algal diversity from River Panjkora.

\section{Materials and methods \\ Study area}

District Dir lower is situated with the longitudes and Latitudes of $34^{0}, 37^{0}$ to $35^{\circ}$, $07^{0}$ North and $71^{0}, 31^{0}$ to $72^{0}$ to $14^{0}$ East. District Dir is approximately 830 meters above the sea level, experiencing the annual rain falls is $1468 \mathrm{~mm}$. It has a boundary with district Chitral on the Northern side, With Bajour and Afghanistan on the Western side, with district Malakand on the southern side, with district Swat on the eastern side. The river Panjkora is a river in Khyber Pakhtunkhwa, Pakistan. It originates from the Kohistan Dir upper mountains passing upper and Lower Dir. River Panjkora then joins with river Swat at Sharbatti Bosoq Pull, behind the Totakan district Malakand and then connects with River Kabul at Charsadda in the Peshawar valley.

\section{Collections}

More than 70 samples were collected from different locality of river Panjkora and its surrounding. Algal species were collected in a clean plastic bottle with a capacity of 1 liter from the different site of fresh water bodies in river Panjkora. The collected water is from the depth of 1-3 feet's below the surface waters. The species is collected through hands picking, forceps, direct put the water in bottles.

\section{Preservations and identifications}

The algal species is preserved with $4 \%$ formalin [12]. Aquatic algal species were preserved with 8\%feramlin, and phytoplankton was preserved with 2\%feramilin. The algal species were identified with the available literature like [13-16].

\section{Results and discussion}

The present's research work is focusing on the exploring of algal species from the river Panjkora district Dir Lower, KPK, Pakistan. The algal diversity in the River Panjkora and its surrounding lakes and streams are rich. The algal species were collected, identified in the river Panjkora for the first time. In our collection, the most dominant Phylum Chlorophyta includes 22 (63\%) species, Charophyta $6(17 \%)$ species, Euglenophyta $4(11 \%)$ Species, Ochrophyta $2(6 \%)$ species and Rhodophyta $1(3 \%)$ species shown in the (Figure 1). While the Genus Euglena 4(24\%), Genera Ankistrodesmus, Microspora, Spirogyra and Ulothrix has 3 Species (17\%), Genera Chaetophora, Chlamydomonas, Cladophora, Nitella, Oocystis, Stigeoclonium, and Volvox has 2 species (12\%), Asterococcus, Batrachospermum, Chlorochromonas, Synura, Zygogonium each has 1 species (6\%) Shown in the (Figure 2) the same results from the various freshwater habitats algal species is taxonomically identified and 
explored from various parts of Pakistan by Hussain et al. [5], Leghari et al. [6] and Hussain et al. [4]. The same results from Karachi in fresh water fresh water algae habitats revealed by Aliya et al [7], Leghari [8], the taxonomic survey of freshwater algae from Multan by Ghazala et al. [9]. A total of 68 blue green algal species belonging to 29genera documented from various habitats like rivers, streams, ponds, stagnant water and waste water documented from district Malakand KPK, Pakistan by Hussain et al. [17]. The same results from
Baluchistan a checklist of freshwater algae documented and identified by Hussain et al. [4]. The $\mathrm{pH}$ of different water bodies from various freshwater algal habitats, stagnant and running water and waste water bodies explain by Hussain et al. [18]. The algal diversity observed in wastewater bodies which is dominated in algal blooms during summer seasons by Hussain and Shah [19]. Freshwater algal species belong to 6 genera from the various site of Peshawar valley documented by Hussain et al. [20].

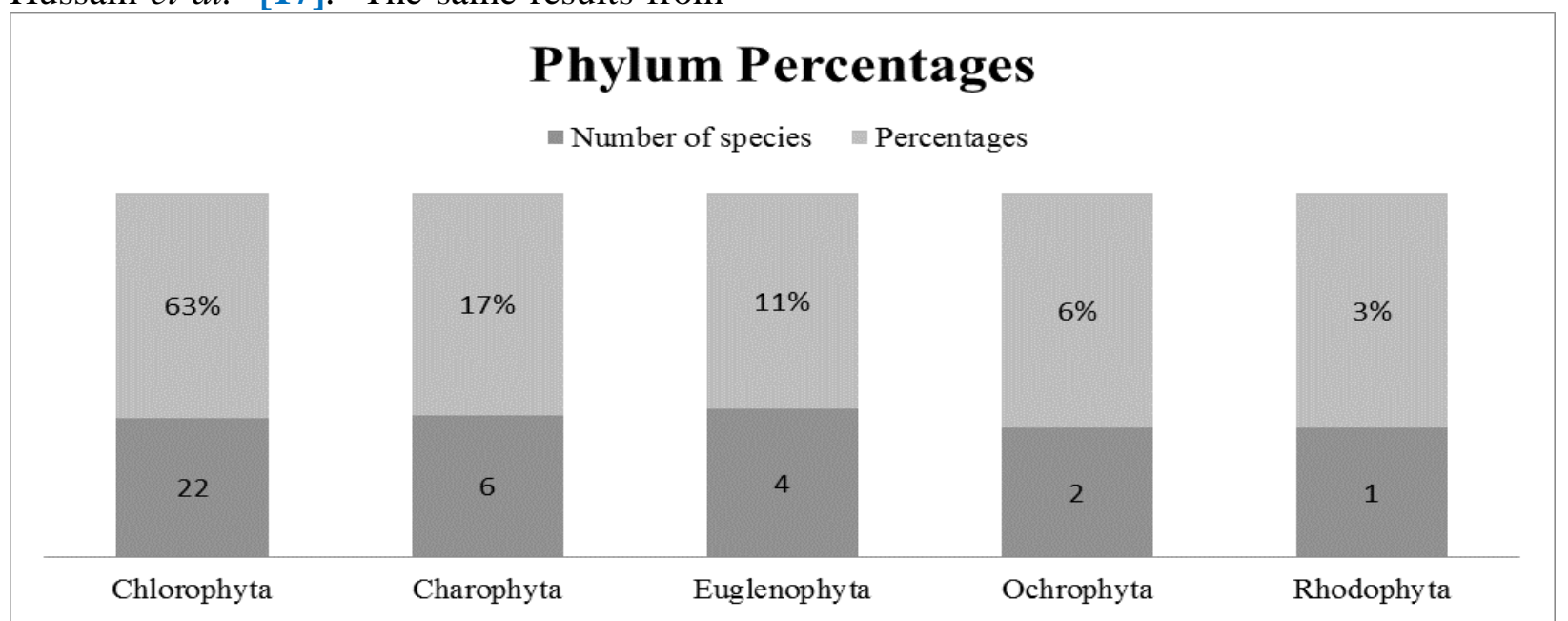

Figure 1. It shows us the Phylum percentages, number of species in the river Panjkora KPK, Pakistan

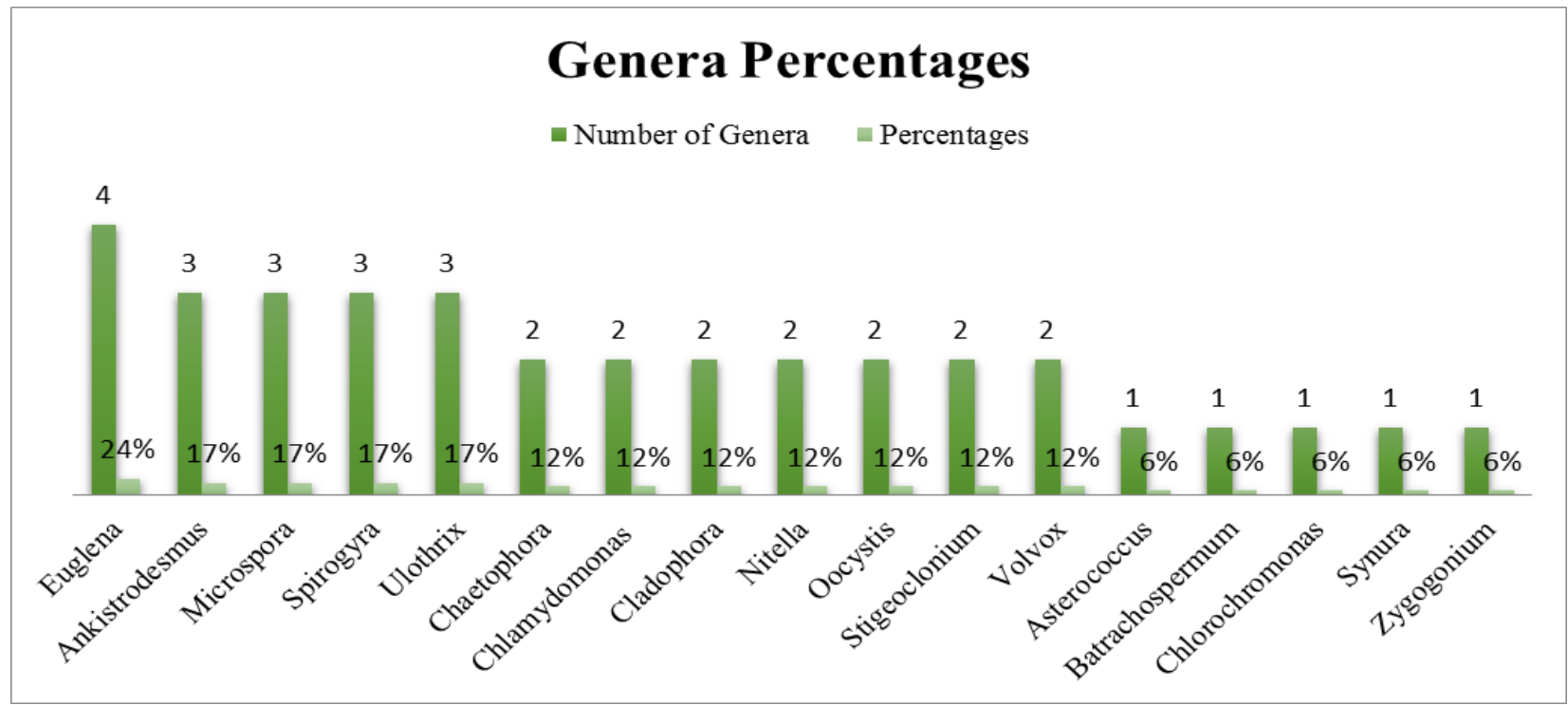

Figure 2. It shows us the number of Genus and its percentages in river Panjkora KPK, Pakistan 


\section{Hajiabad}

The total algae species in record Hajiabad near river Panjkora are Nitella flexilis, Spirogyra aequinoctialis, Spirogyra scrobiculata, Zygogonium ericetorum, Ankistrodesmus fractus, Ankistrodesmus falcatus, Asterococcus limneticus, Chlamydomonas angulosa, Chlamydomonas glohosa, Cladophora glomerata, Microspora floccose, Microspora loefgrenii, Oocystis elliptica, Stigeoclonium flagelliferum, Stigeoclonium lubrium, Ulothrix zonata, Volvox globator, Euglena Table 1. Relative distribution of algal species in among the different sites of river Panjkora

\begin{tabular}{|l|l|l|l|l|l|l|}
\hline S.No & Algal species & Hajiabad & Daab & Kandaroo & Tarai & ShagoKaas \\
\hline 1 & Nitella flexilis & + & + & - & - & - \\
\hline 2 & Nitella tenuissima & - & + & + & + & - \\
\hline 3 & Spirogyra aequinoctialis & + & + & + & + & + \\
\hline 4 & Spirogyra scrobiculata & + & + & - & + & + \\
\hline 5 & Spirogyra weberi & - & + & + & - & + \\
\hline 6 & Zygogonium ericetorum & + & - & - & - & - \\
\hline 7 & Ankistrodcsmus fractus & + & - & - & + & + \\
\hline 8 & $\begin{array}{l}\text { Ankistrodescmus convolutes } \\
\text { Corda }\end{array}$ & - & - & + & + & - \\
\hline 9 & Ankistrodesmus falcatus & + & + & + & - & - \\
\hline 10 & $\begin{array}{l}\text { Asterococcus limneticus G.M. } \\
\text { Smith }\end{array}$ & + & - & - & + & + \\
\hline 11 & Chaetophora attenuate Hazen & - & + & + & - & - \\
\hline 12 & $\begin{array}{l}\text { Chaetophora elegans } \\
\text { Schrank, } 1783\end{array}$ & - & + & + & - & - \\
\hline 13 & Chlamydomonas angulosa & + & + & - & + & + \\
\hline 14 & Chlamydomonas glohosa & + & - & - & + & + \\
\hline 15 & Cladophora fracta & - & + & + & + & - \\
\hline 16 & Cladophora glomerata & + & - & + & - & - \\
\hline 17 & Microspora crassior & - & + & - & - & + \\
\hline 18 & Microspora floccose & + & + & + & + & - \\
\hline 19 & Microspora loefgrenii & + & - & - & - & + \\
\hline 20 & Oocystis crassa & - & - & + & + & - \\
\hline 21 & Oocystis elliptica & + & + & - & - & + \\
\hline 22 & Stigeoclonium flagelliferum & + & - & - & + & - \\
\hline 23 & Stigeoclonium lubricum & + & - & - & + & + \\
\hline 24 & Ulothrix equalis & - & + & + & - & + \\
\hline 25 & Ulothrix cylindricum & - & + & - & + & - \\
\hline 26 & Ulothrix zonata & + & - & + & + & - \\
\hline 27 & Volvox aureus & - & - & + & - & + \\
\hline & & & & & \\
\hline
\end{tabular}




\begin{tabular}{|l|l|l|l|l|l|l|}
\hline 28 & Volvox globator & + & + & - & + & - \\
\hline 29 & Euglena acus & + & - & + & + & + \\
\hline 30 & Euglena gracilis & - & + & - & - & + \\
\hline 31 & Euglena oxyuris & + & - & + & - & + \\
\hline 32 & Euglena proxima & + & + & - & + & - \\
\hline 33 & Chlorochromonas minuta & - & - & + & + & + \\
\hline 34 & Synura vella & - & + & - & - & + \\
\hline 35 & Batrachospermummoniliforme & + & + & - & - & - \\
\hline
\end{tabular}

Table 2. Physico-chemical analysis of water samples taken from various algal water bodies in river Panjkora various sites Dir Lower, Pakistan

\begin{tabular}{|l|l|l|l|l|l|l|}
\hline \multirow{2}{*}{ Paramenters } & \multicolumn{5}{|c|}{ Collection sites } & $\begin{array}{l}\text { WHO } \\
\text { Suggested } \\
\text { limit }\end{array}$ \\
\cline { 2 - 7 } & Hajiabad & Daab & Kandaro & Tarai & $\begin{array}{l}\text { Shago } \\
\text { Kaas }\end{array}$ \\
\hline pH & 7.90 & 8.02 & 7.21 & 7.39 & 8.50 & $6.5-9.2$ \\
\hline Conductivity $\mu$ S/cm & 700.00 & 680.00 & 690.00 & 691.00 & 695.00 & 1000 \\
\hline Total solids $(\mathrm{TS}) \mathrm{mg} / \mathrm{L}$ & 890 & 1250 & 910 & 1025.1 & 975 & 1000 \\
\hline $\begin{array}{l}\text { Total dissolved solids } \\
\text { (TDS)mg/L }\end{array}$ & 900 & 720 & 800 & 2010 & 1098.64 & 1000 \\
\hline $\begin{array}{l}\text { Total suspended solids } \\
\text { (TSS)mg/L }\end{array}$ & 4 & 5 & 5.636 & 4.362 & 14.232 & 5 \\
\hline Total hardness $(\mathrm{TH}) \mathrm{mg} / \mathrm{L}$ & 220 & 338.6 & 615 & 517 & 425 & 500 \\
\hline Calcium as $\mathrm{CaCo}_{3} \mathrm{mg} / \mathrm{L}$ & 164.50 & 192 & 184 & 172 & 179 & 248.00 \\
\hline Magnisium as CaCo $\mathrm{mg} / \mathrm{L}$ & 156 & 164 & 172 & 133 & 156 & 150 \\
\hline M-alkalinity as CaCo $\mathrm{mg} / \mathrm{L}$ & 302.25 & 308.50 & 335.50 & 320.50 & 323 & 500 \\
\hline P-alkalinity as $\mathrm{CaCo} 3 \mathrm{mg} / \mathrm{L}$ & - & - & - & - & - & 30 \\
\hline Sulphates as $\mathrm{SO}_{4}{ }^{-2} \mathrm{mg} / \mathrm{L}$ & 305 & 95.5 & 280 & 200 & 312 & 250 \\
\hline Potassium as $\mathrm{K}^{+1} \mathrm{mg} / \mathrm{L}$ & 21.3 & 6.293 & 7.273 & 20.00 & 13.7 & 75 \\
\hline Chlorides as $\mathrm{Cl}^{-1} \mathrm{mg} / \mathrm{L}$ & 73.50 & 72 & 26 & 45 & 36.75 & 250 \\
\hline Sodium as $\mathrm{Na}^{+1} \mathrm{mg} / \mathrm{L}$ & 120 & 250 & 166.5 & 180 & 230 & 200 \\
\hline Nitrates as $\mathrm{NO}_{2}{ }^{-1} \mathrm{mg} / \mathrm{L}$ & 1.8 & 0.5 & 2.0 & 1.6 & 0.8 & .5 \\
\hline
\end{tabular}

\section{Daab (College Khawar)}

The total algal species recorded in Daab are Nitella flexilis, Nitella tenuissima, Spirogyra aequinoctialis, Spirogyra scrobiculata, Spirogyra weberi, Ankistrodesmus falcatus, Chaetophora attenuate, Chaetophora elegans, Chlamydomonas angulosa, Cladophora fracta, Microspora crassior, Microspora floccose, Oocystis elliptica, Ulothrix equalis, Ulothrix cylindricum, Volvox globator, Euglena gracilis, Euglena proxima, Synura vella and Batrachospermum moniliforme shown in (Table 1). The $\mathrm{pH} 8.02$, conductivity 680 $\mu \mathrm{S} / \mathrm{cm}$, Total Solids (TS) $1250 \mathrm{mg} / \mathrm{L}$, Total dissolved solids (TDS) 720mg/L, Total suspended Solids (TDS) 5mg/L, Total Hardness (TH) $338.6 \mathrm{mg} / \mathrm{L}$, Calcium as $\mathrm{CaCO}_{3} 192 \mathrm{mg} / \mathrm{L}$, Magnesium as $\mathrm{CaCO}_{3}$ $164 \mathrm{mg} / \mathrm{L}, \quad$ M-alkalinity as $\mathrm{CaCO}_{3}$ $308.50 \mathrm{mg} / \mathrm{L}, \quad$ P-alkalinity as $\mathrm{CaCO}_{3}$ nil $\mathrm{mg} / \mathrm{L}, \quad$ Sulphate as $\mathrm{SO}_{4}^{-2} \quad 95.5 \mathrm{mg} / \mathrm{L}$, Potassium as $\mathrm{K}^{+1} 6.293 \mathrm{mg} / \mathrm{L}$, Chlorides as $\mathrm{Cl}^{-1} 72 \mathrm{mg} / \mathrm{L}$, Sodium as $\mathrm{Na}^{+1} 250 \mathrm{mg} / \mathrm{L}$ and Nitrates as $\mathrm{NO}_{2}^{-1} 0.5 \mathrm{mg} / \mathrm{L}$ shown in (Table 2).

\section{Kandaroo}

The algal species recorded in Kandroo on the side of river Panjkora are Nitella tenuissima, Spirogyra aequinoctialis, Spirogyra weberi, Ankistrodesmus convolutes, Ankistrodesmus falcatus, 
Chaetophora attenuate, Chaetophora elegans, Cladophora fracta, Cladophora glomerata, Microspora floccose, Oocystis crassa, Ulothrix equalis, Ulothrix zonata, Volvox aureus, Euglena acus, Euglena oxyuris and Chlorochromonas minuta Shown in (Table 1). The pH 7.21, Conductivity $680.00 \mu \mathrm{S} / \mathrm{cm}$, Total solids (TS) $910 \mathrm{mg} / \mathrm{L}$, Total dissolved solids (TDS) $800 \mathrm{mg} / \mathrm{L}$, Total suspended solids (TSS) $5.636 \mathrm{mg} / \mathrm{L}$, Total hardness $(\mathrm{TH}) 615 \mathrm{mg} / \mathrm{L}$, Calcium as $\mathrm{CaCO}_{3} \quad 184 \mathrm{mg} / \mathrm{L}$, Magnesium as $\mathrm{CaCO}_{3} 172 \mathrm{mg} / \mathrm{L}$, M-alkalinity as $\mathrm{CaCO}_{3}$ $335.50 \mathrm{mg} / \mathrm{L}, \quad$ P-alkalinity as $\mathrm{CaCO}_{3}$ nil $\mathrm{mg} / \mathrm{L}$, Sulphate as $\mathrm{SO}_{4}{ }^{-2} \quad 280 \mathrm{mg} / \mathrm{L}$, Potassium as $\mathrm{K}^{+1} 7.273 \mathrm{mg} / \mathrm{L}$, Chlorides as $\mathrm{Cl}^{-1} 26 \mathrm{mg} / \mathrm{L}$, Sodium as $\mathrm{Na}^{+1} 166.5 \mathrm{mg} / \mathrm{L}$ and Nitrates $\mathrm{NO}_{2}^{-1} 2.0 \mathrm{mg} / \mathrm{L}$ Shown in the (Table 2).

\section{Tarai}

The total algal species recorded in the Tarai in the side of River Panjkora are Nitella tenuissima, Spirogyra aequinoctialis, Spirogyra scrobiculata, Ankistrodesmus fractus, Ankistrodesmus convolutes, Asterococcus limneticus, Chlamydomonas angulosa, Chlamydomonas glohosa, Cladophora fracta, Microspora floccose, Oocystis crassa, Stigeoclonium flagelliferum, Stigeoclonium lubricum, Ulothrix cylindricum, Ulothrix zonata, Volvox globator, Euglena acus, Euglena proxima and Chlorochromonas minuta Shown in (Table 1). The pH 7.39, Conductivity $691.00 \mu \mathrm{S} / \mathrm{cm}$, Total solids (TS) $1025.1 \mathrm{mg} / \mathrm{L}$, Total dissolved solids (TDS) $2010 \mathrm{mg} / \mathrm{L}$, Total suspended solids (TSS) $4.362 \mathrm{mg} / \mathrm{L}$, Total hardness $(\mathrm{TH})$ $51 \mathrm{mg} / \mathrm{L}$, Calcium as $\mathrm{CaCO}_{3} 172 \mathrm{mg} / \mathrm{L}$, Magnesium as $\mathrm{CaCO}_{3} \quad 133 \mathrm{mg} / \mathrm{L}, \quad \mathrm{M}-$ alkalinity as $\mathrm{CaCO}_{3} \quad 320.50 \mathrm{mg} / \mathrm{L}, \quad \mathrm{P}-$ alkalinity as $\mathrm{CaCO}_{3}$ nil $\mathrm{mg} / \mathrm{L}$, Sulphates as $\mathrm{SO}_{4}{ }^{-2} \quad 200 \mathrm{mg} / \mathrm{L}, \quad$ Potassium as $\mathrm{K}^{+1}$ $20.00 \mathrm{mg} / \mathrm{L}$, Chlorides as $\mathrm{Cl}^{-1} 45 \mathrm{mg} / \mathrm{L}$, Sodium as $\mathrm{Na}^{+1} 180 \mathrm{mg} / \mathrm{L}$ and Nitrates as $\mathrm{NO}_{2}{ }^{-1} 1.6 \mathrm{mg} / \mathrm{L}$ Shown in the (Table 2).

\section{ShagoKaas}

The total species recorded in ShagoKaas near river Panjkora are Spirogyra aequinoctialis, Spirogyra scrobiculata, Spirogyra weberi, Ankistrodesmus fractus, Asterococcus limneticus, Chlamydomonas angulosa, Chlamydomonas glohosa, Microspora crassior, Microspora loefgrenii, Oocystis elliptica, Stigeoclonium lubricum, Ulothriz equalis, Volvox aureus, Euglena acus, Euglena gracilis, Euglena oxyuris, Chlorochromonas minuta and Synura vella shown in (Table 1). The pH 9.50, Conductivity $695 \mu \mathrm{S} / \mathrm{cm}$, Total Solids (TS) 975mg/L, Total dissolved Solids (TDS) $1098.64 \mathrm{mg} / \mathrm{L}$, Total suspended Solids (TSS) $14.232 \mathrm{mg} / \mathrm{L}$, Total Hardness (TH) $425 \mathrm{mg} / \mathrm{L}$, Calcium as $\mathrm{CaCO}_{3} 179 \mathrm{mg} / \mathrm{L}$, Magnesium as $\mathrm{CaCO}_{3} \quad 156 \mathrm{mg} / \mathrm{L}, \quad \mathrm{M}-$ alkalinity as $\mathrm{CaCO}_{3} 323 \mathrm{mg} / \mathrm{L}$, P-alkalinity as $\mathrm{CaCO}_{3}$ nil $\mathrm{mg} / \mathrm{L}$, Sulphates as $\mathrm{SO}_{4}{ }^{-2}$ $312 \mathrm{mg} / \mathrm{L}$, Potassium as $\mathrm{K}^{+1} 13.7 \mathrm{mg} / \mathrm{L}$, Chlorides as $\mathrm{Cl}^{-1} 36.75 \mathrm{mg} / \mathrm{L}$, sodium as $\mathrm{Na}^{+1} 230 \mathrm{mg} / \mathrm{L}$ and Nitrates as $\mathrm{NO}_{2}{ }^{-1}$ $0.8 \mathrm{mg} / \mathrm{L}$ as shown in the (Table 2).

Taxonomic description of algal species Phylum Rhodophyta

\section{Batrachospermum moniliforme (Figure-3,} Plate-1)

It is a freshwater alga species and found in cold running water. It is soft thick and chains like Floridian starch are present. Cell size maximums $10-17 \mu$ in diameter and 11 $16 \mu$ long.

\section{Phylum Ochrophyta}

\section{Synura vella (Figure-3, Plate-2)}

The cell is cylindrical, thallus is small and elongated. Cell size maximums $7-8 \mu$ in diameter and 6-7 $\mu$ long.

\section{Chlorochromonas minuta (Figure-3, Plate-} 3)

It is fresh water algae found in cold running water. It is soft thick and chains like Floridian starch are present. Cell size maximums $10-17 \mu$ in diameter and $11-16 \mu$ long. 


\section{Phylum Euglenophyta}

Euglena acus (Figure-3, Plate-4)

The cell is green having chloroplast. Cell size maximums $13-17 \mu$ in diameter and 11$16 \mu$ long.

Euglena gracilis (Figure-3, Plate-5)

The thallus is green and forms a large ball like structure. Cell size maximums $14-17 \mu$ in diameter and $12-16 \mu$ long.

\section{Euglena oxyuris (Figure-3, Plate-6)}

The cell is green and forms a large ball like structure. Cell size maximums $13-17 \mu$ in diameter and 11-16 $\mu$ long.

Euglena proxima (Figure-3, Plate-7)

The body is green and forms a large ball like structure. Cell size maximums $14-17 \mu$ in diameter and $14-19 \mu$ long.
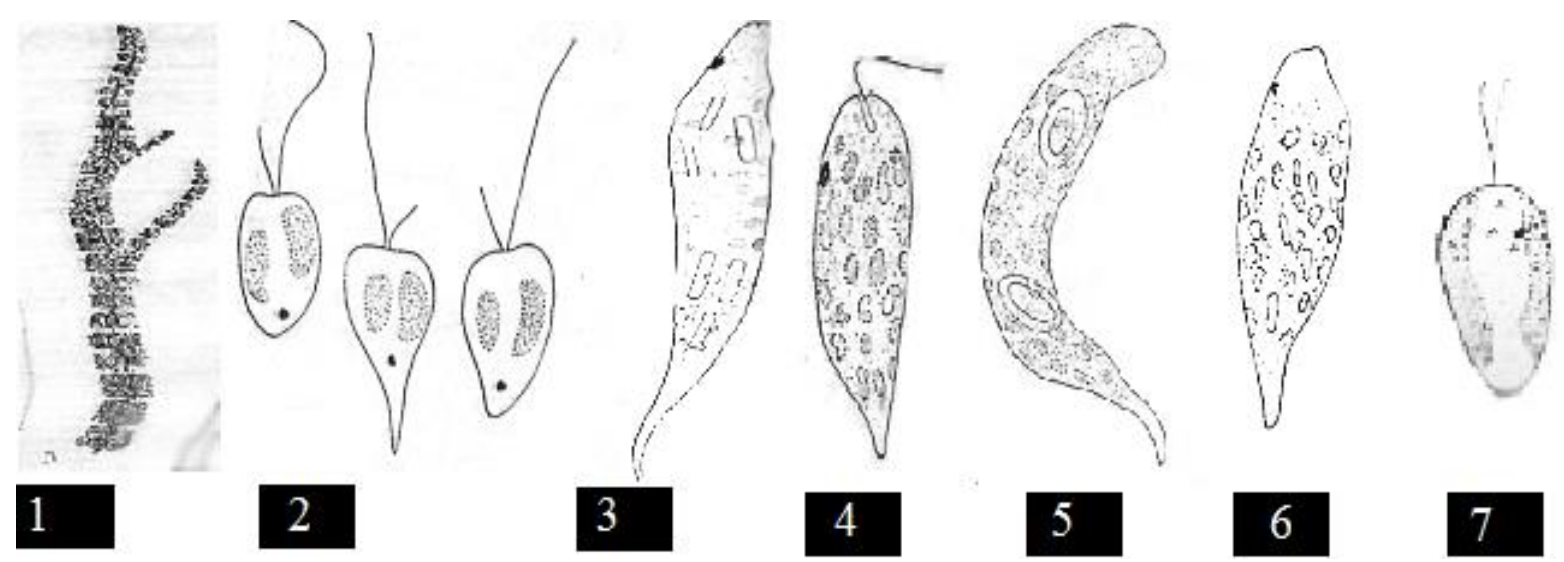

Figure 3. It include species 1) Batrachospermum moniliforme 2) Chlorochromonas minuta 3) Euglena acus 4) Euglena gracilis 5) Euglena oxyuris 6) Euglena proxima 7) Synura uvella

\section{Phylum Chlorophyta}

Ankistrodesmiis fractus (West and G. S.

West) Collins 1912 (Figure 4, Plate-8)

This species has needle like cells, rather spindle shaped, sometime clusters of 232individual or solitary. It has no colonial sheath chloroplast, a parietal plate without pyrenoids, the cell is $2-6 \mu$ in diameter and 25-100 $\mu$ long, sometimes more than this. Ubiquitous; intermingled with other temperatures, where there is a dense collection of unicellular and colonial algae.

\section{Ankistrodesmiis convolutes (Figure-4, Plate-9)}

It may be solitary or group of cells 2-4cells, fusiform in shape, warped and sigmoid. The tips is sharply pointed and sometimes twisted in opposite directions. Cell size maximums $3-5 \mu$ in diameter and $15-30 \mu$ long

Key to species

Cell may be straight, irregular in clusters, somewhat twisted about one another.

Ankistrodesmus falcatus (Figure 4, Plate10)

The thallus of this species is elongated and little bit fusiform. Cell size maximums $2-4 \mu$ in diameter and 4-10 $\mu$ long.

Asterococcus limneticus G.M. Smith (Figure 4, Plate-11)

The cell is cylindrical the cell wall of this species is cellulosic, Cell size maximums 3$4 \mu$ in diameter and 6-10 $\mu$ long.

Chaetophora attenuate Hazen (Figure 4, Plate-12) 
Wall of the main axial cell is $5-6 \mu$ in diameter and 6-8 $\mu$ long. Branching very irregular with long and tapering as well short, Arbuscular or rhizoidal branch produced throughout the length of the main axis.

Chaetophora elegans F. Schrank, 1783 (Figure 4, Plate-13)
Thallus pesudoparenchyma, stouter cell. Wall of main axial cell is $3-6 \mu$ in diameter and 5-8 $\mu$ long.

\section{Chlamydomonas angulosa (Figure 4, Plate-14)}

Cell have flagella, chloroplast is present in form of cup-shaped. Cell size maximums 4$8 \mu$ in diameter and $8-10 \mu$ long.

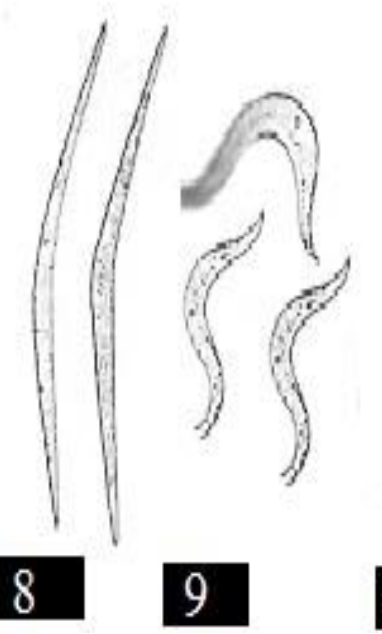

Figure 4. It include the species 8) Ankistrodcsmus fractus, 9) Ankistrodesmus convolutus 10) Ankistrodesmus falcatus 11) Asterococcus limneticus 12) Chaetophora attenuate 13) Chaetophora elegans 14) Chlamydomonas angulosa
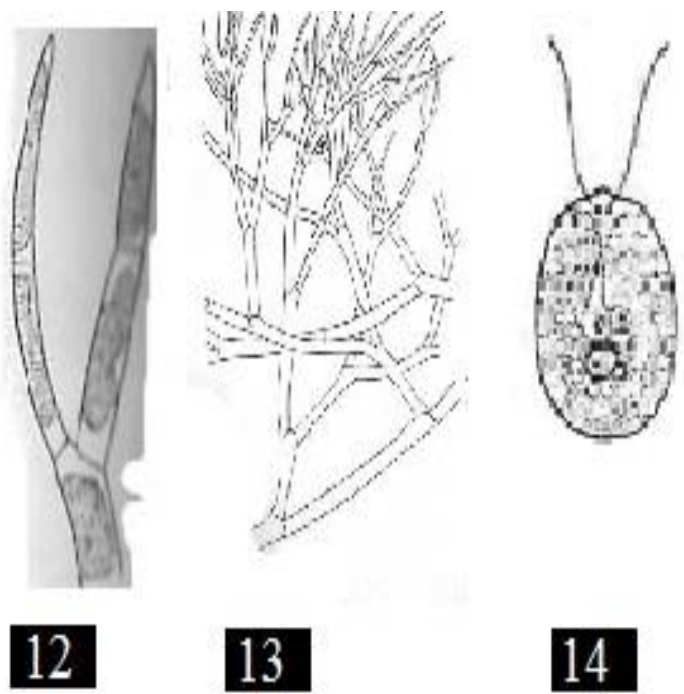

Chlamydomonas glohosa (Figure 5, Plate-

\section{5)}

Cell have flagella, chloroplast is present. Cell size maximums $2-6 \mu$ in diameter and 5$10 \mu$ long.

\section{Cladophora fracta (Figure 5, Plate-16)}

The thallus is green due to presences of chlorophyll. The cell is cylindrical there is great variability in this species and have many species and forms. Cell size maximums $5-6 \mu$ in diameter and $7-10 \mu$ long.

\section{Cladophora glomerata (Figure 5, Plate-17)}

Chlorophyll is present, thallus is cylindrical. Cell size maximums $5-8 \mu$ in diameter and 5$8 \mu$ long.

Microspora crassior. (Figure 5, Plate-18)

The thallus is small while the cells are rounded in outline. The majority of species have chlorophyll. The cell is cylindrical there is great variability in this species and have many species and forms. Cell size maximums $7-8 \mu$ in diameter and $3-7 \mu$ long.

Microspora floccose (Figure 5, Plate-19)

The cell is cylindrical, chlorophyll is present. Cell size maximums $6-8 \mu$ in diameter and 5-7 $\mu$ long.

Microspora loefgrenii (Figure 5, Plate-20)

The cell is cylindrical, thallus is small and green. Cell size maximums $7-8 \mu$ in diameter and $5-7 \mu$ long.

\section{Oocystis crassa (Figure 5, Plate-21)}

It is a freshwater alga found in cold running water, It is soft thick and chains like Floridian starch are present. Cell size maximums $10-17 \mu$ in diameter and $11-16 \mu$ long. 

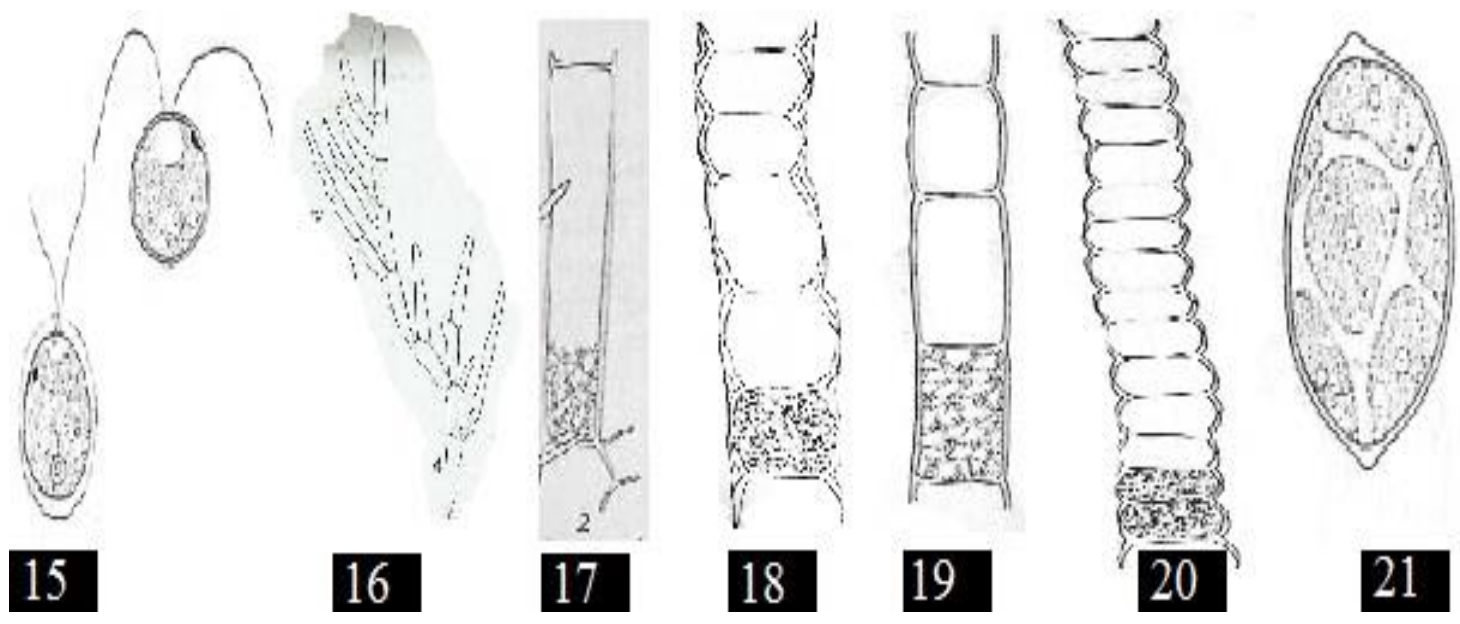

Figure 5. It includes the species 15) Chlamydomonas glohosa 16) Cladopora fracta 17) Cladopora glomerata 18) Microspora crassior 19) Microspora floccose 20) Microspora loefgrenii 21) Oocystis crassa

\section{Oocystis elliptica (Figure 6, Plate-22)}

Oocystis elliptica is a freshwater green algae species. The cell is slightly swollen and almost spherical; size is $6.8-16.5 \mu \mathrm{m}$ wide and 11-25 $\mu \mathrm{m}$ long, oval to sub-cylindrical apices broadly rounded and without polar wall thickenings. The chloroplast is a large 10-20per cell, without pyrenoids, auto-spore 4-8 per sporangium, each have several chloroplasts.

\section{Stigeoclonium flagelliferum (Figure 6,} Plate-23)

Has erected which is densely branched at the base while a branch of the upper portion is irregular. Cell size maximums $6-7 \mu$ in diameter and 4-7 $\mu$ long.

Stigeoclonium lubricum (Figure 6, Plate24)

The thallus is elongated, having branch also on the apex. Cell size maximums $2-7 \mu$ in diameter and $4-9 \mu$ long.

\section{Ulothrix equalis (Figure 6, Plate-25)}

It may be solitary, fusiform in shape, the tips is sharply pointed and sometimes twisted in opposite directions. Cell size maximums 4$5 \mu$ in diameter and 5-30 $\mu$ long.

\section{Ulothrix cylindricum (Figure 6, Plate-26)}

This is filamentous algae, having flagella. They form colonies which are surrounded by a sheath. Cell size maximums $12-17 \mu$ in diameter and 14-16 $\mu$ long.

\section{Ulothrix zonata (Figure 6, Plate-27)}

Filamentous algae, having flagella, Cell is surrounded by a sheath. Cell size maximums $12-17 \mu$ in diameter and $14-16 \mu$ long.

Volvox aureus (Figure 6, Plate-28)

Green filamentous algae, having flagella, they form colonies which are surrounded by sheath. Cell size maximums $12-17 \mu$ in diameter and 14-16 $\mu$ long.

\section{Volvox globator (Figure 6, Plate-29)}

The thallus is green and forms a large ball like structure. Cell size maximums $14-17 \mu$ in diameter and 12-16 $\mu$ long. 


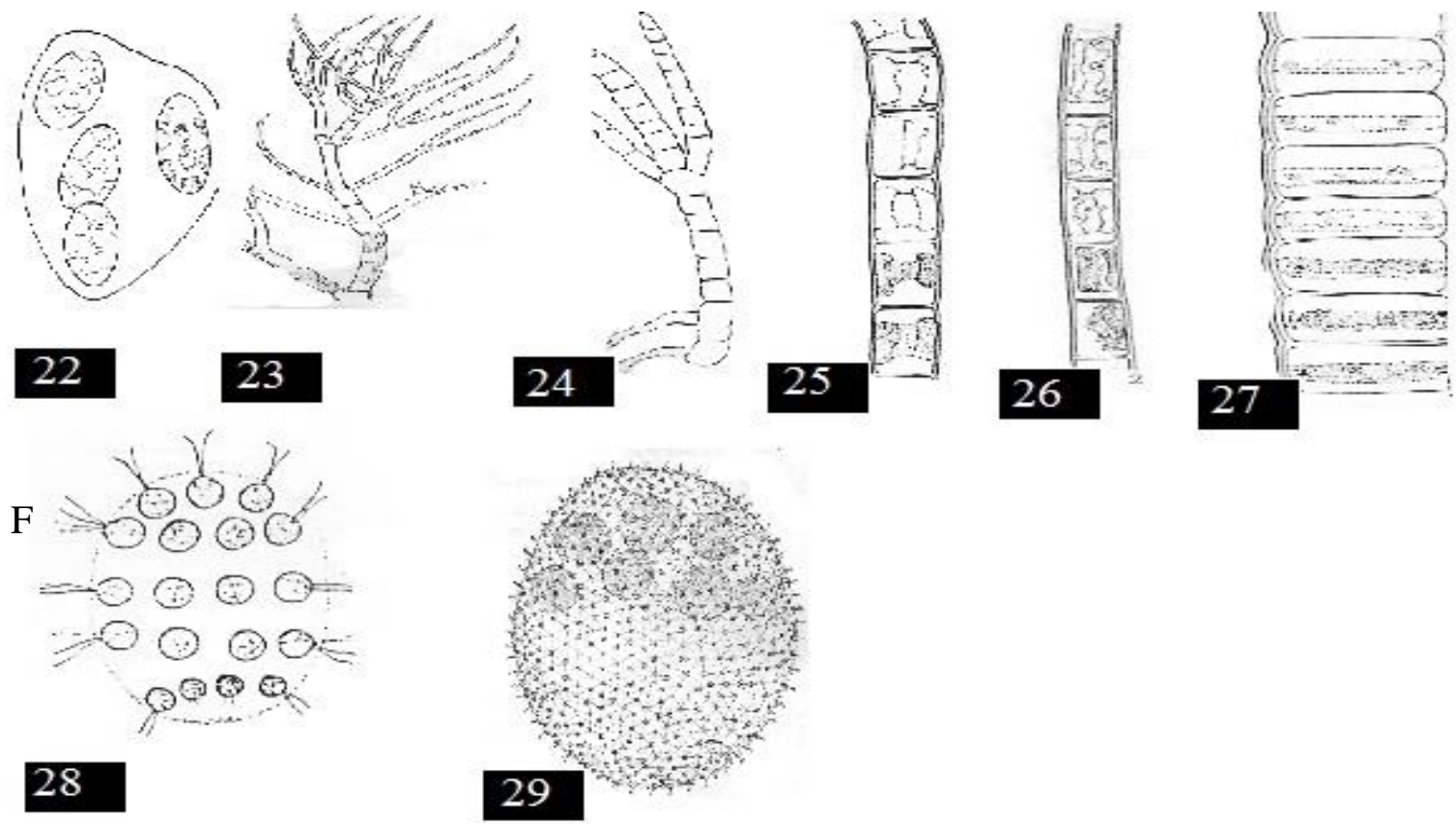

Figure 6. It includes the species 22) Oocystis elliptica 23) Stigeoclonium flagelliferum 24) Stigeoclonium luhricum 25) Ulothrix aequalis 26) Ulothrix cylindricum 27) Ulothrix zonata 28) Volvox aureus 29) Volvox globator

Nitella flexilis (Figure 7, Plate-30)

It is Smooth stonewort in fresh water. It grows in a meter long and $1 \mathrm{~mm}$ wide. Cell size of this species maximums $12-18 \mu$ in diameter and 11-17 $\mu$ in long.

Nitella tenuissima (Figure 7, Plate-31)

This is algae having filaments; they form colonies which are surrounded by a sheath. Cell size maximums $13-17 \mu$ in diameter and 10-16 $\mu$ long.

Spirogyra aequinoctialis (Figure 7, Plate32)

This species has a cylindrical cell, chloroplast sometime many sometimes in the group which makes 5-6 turn. The cell wall of this species is scrobiculate, spindle shape having a diameter of $3-7 \mathrm{~m}$ in diameter.
Spirogyra scrobiculata (Figure 7, Plate-33) The thallus of this is cylindrical, many chloroplasts are present which make 15-17 turn. The cell wall of this species is scrobiculate, spindle shape having diameter of $3-4 \mathrm{~m}$ in diameter.

Spirogyra weberi (Figure 7, Plate-34)

This specie sometime present in groups and sometime in groups, Thallus is elongated have $2-4 \mathrm{~m}$ in diameter. Pyrenoids are located at their sides.

Zygogonium ericetorum (Figure 7, Plate35)

The cell of this algae is elongated, it form sometime group. The cell is 3-6 $\mu$ in diameter and 15-41 $\mu$ long. 


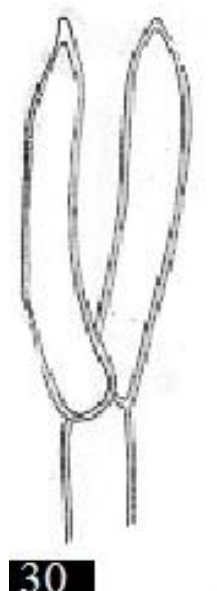

30

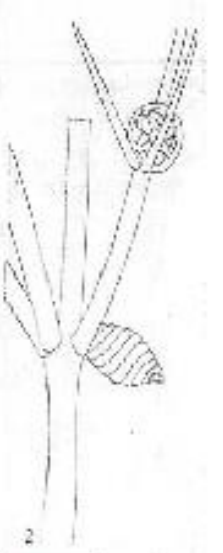

31

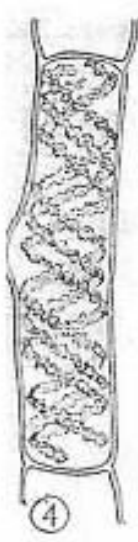

32

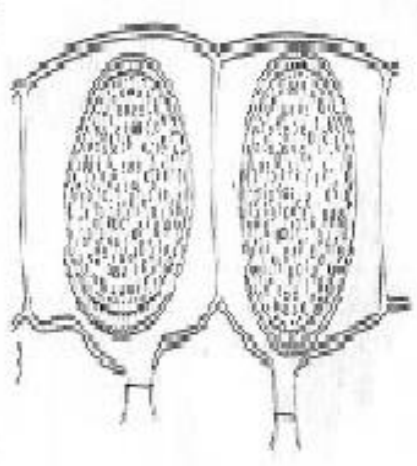

33

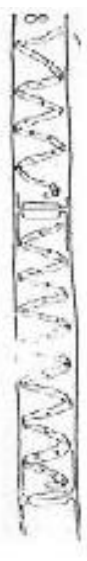

34

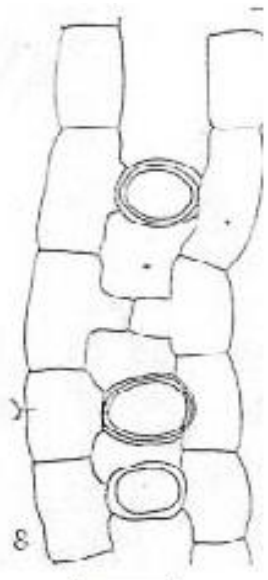

35

Figure 7. It includes the species 30) Nitellaflexilis 31) Nitella tenuissima 32) Spirogyra aequinoctialis 33) Spirogyra scrobiculata 34) Spirogyra weberi 35) Zygogonium ericetorum

\section{Conclusion}

District Dir lower has river, lakes, streams and other fresh water bodies where algae are in abundance and district Dir lower is the most ignored area of aquatic botany. The current investigations is done is river Panjkora different sites and found 35 species belong to 5 phylum, 9 classes, 12 order, 15 families and 16 genera. The area is rich of algal flora and further study is needed under this record.

\section{Authors' contributions}

Conceived and designed the experiments: $\mathrm{M}$ Shuaib, Performed the Fields work and experiments: M Shuaib \& K Ali, Analyzed the data: U Zeb, S Ahmed \& S Ali, Contributed reagents/ materials/ analysis tools: S Ali, I Khan \& F Hussain, Wrote the paper: M Shuaib \& F Hussain.

\section{Acknowledgments}

I am thankful to my Parents and Uncle Muhammad Layaq for helping me in collection of algal species. Special thanks are extended to the Journal reviewers for their useful comments.

\section{References}

1. Geoghegan M (1951).Unicellular algae as a source of food. Nature 168(4271): 426427.
2. John DM, Whitton BA \& Brook AJ (2002). The freshwater algal flora of the British Isles: an identification guide to freshwater and terrestrial algae. Cambridge University Press Vol. 1: ISBN 0521770513.

3. Sarim F (2005). The fresh water algae of Bara river Peshawar, Pakistan. Pak J Pl Sci 11(1): 133-136.

4. Hussain F, Zaidi MI \& Durrani MJ (2003). A checklist to the algae of Upper Balochistan. Pak J Pl Sci 9: 1-86.

5. Hussain F, Anjum G, Akhtar P \& Durrani MJ (2010). Some members of class Xanthophyceae and Euglenophyceae from soils of Peshawar valley, Khyber Pakhtunkhwa, Pakistan. Pakistan Journal of Plant Sciences 16(1).

6. Leghari M, Butt F \& Rehman S (2007). Fresh water algae from Bunkhurme Mirpur, Azad Kashmir. Int J Phycal \& Phycochem 3(1): 29-36.

7. Aliya R, Zarina A \& Shameel M (2008). Survey of freshwater algae from Karachi, Pakistan. Pak J Bot 41(2): 861-870.

8. Leghari S (2001). Some fresh water green filamentous algae (Chlorophyta) and Dinoboroncylindrica (Chrysophyta) from 
Lakes and River in Ponds of Sindh, Pakistan. Online J Biol Sci 1: 145-149.

9. Ghazala B, Hena L, Zarina A \& Shameel M (2009). Taxonomic survey of freshwater algae at the campus of $\mathrm{BZ}$ University of Multan, Pakistan. International Journal of Phycology and Phycochemistry 5(1): 77-92.

10. Shameel M (2006). Taxonomic studies on Cymbella (Bacillariophyta) from Punjab and Azad Kashmir. Pak J Bot 38(1): 161-167.

11. Shuaib M, Khan I, Sharifullah, Khan RD, Hashmatullah Mubarik S \& Naz R (2014). Ethnobotanical studies of spring flora of Dir Lower, Khyber Pakhtunkhwa, Pakistan. Pak J Weed Sci Res 20(1): 37-49.

12. Mason D, Grady I \& Lewis C (1967). 7Chlorolincomycin. Phase II. Medical Brochure 1967: 6-10.

13. Shameel M (2001). An approach to the classification of algae in the new millennium. Pakistan Journal of Marine Biology (Pakistan) 7: 233-250.

14. Shameel M (2008). Change of divisional nomenclature in the Shameelian classification of algae. International Journal of Phycology and Phycochemistry (Pakistan) 4(2): 225232.

15. Shameel M (2012). Nomenclatural changes in the Shameelian classification of algae. International Journal of Phycology and Phycochemistry (Pakistan) 8: 7-22.

16. Hofmann G, Werum $M$ \& LangeBertalot H (2011). Diatomeen in Süßwasser-Benthos von Mitteleuropa. Publisher Gantner verlag K. G pp. 908.

17. Hussain F, Shah SZ \& Hussain Z (2016). Indexing the cyanobacterial communities of different ecological habitats of Malakand Pakistan. Pakistan Journal of Weed Science Research 22(1): 37-47.

18. Hussain F, Shah SZ, Khan MS, Hayat SS \& Khan K (2015). Environmental chemistry and chemical ecology of microalgae affected by $\mathrm{pH}$ : Malakand as a case study. Journal of Biodiversity and Environmental Sciences (JBES) 3: 201206.

19. Hussain F \& Shah SZ (2014). Direct effects of phosphates concentration on the microalgal growth in Malakand Pakistan. Pakistan Journal of Weed Science Research 20(2): 199-206.

20. Hussain F, Leghari MK, Ahmad H, Iqbal A, Saleem M \& Laghari MY (2011).Taxonomic study of freshwater unicellular green algal species from Peshawar valley. International Journal of Phycology and Phycochemistry (Pakistan) 7(1):9-12. 